\title{
Environmental attitudes associated with large-scale cultural differences, not local environmental conflicts
}

\author{
KRISTIN E. GANGAAS ${ }^{1 *}$ BJØRN P. KALTENBORN ${ }^{2}$ AND HARRY P. ANDREASSEN ${ }^{1}$ \\ ${ }^{1}$ Hedmark University College, Faculty of Applied Ecology and Agricultural Sciences, Campus Evenstad, No-2480 Koppang, Normay, and \\ ${ }^{2}$ Normegian Institute of Nature Research (NINA), No-2624 Lillehammer, Norway \\ Date submitted: 8 August 2013; Date accepted: 28 February 2014; First published online 09 April 2014
}

\section{SUMMARY}

Species and ecosystems are under constant pressure from a rapidly-growing human population. Human tolerance of carnivores, including the willingness to live in areas with these predators, is key to the success of large carnivore conservation. In the Scandinavian Peninsula, large carnivore populations conflict with human activity; low tolerance among local people may lead to illegal hunting. A survey of 2521 Scandinavian respondents to measure environmental value orientation, using the new environmental paradigm (NEP) scale and attitudes toward large carnivores, revealed attitudes towards the presence of carnivores were not related to carnivore abundance. Nor was there a significant relationship between environmental value orientation and personal experiences with loss of domestic sheep or hunting dogs. Environmental values were mainly explained by country differences; Swedes had a more ecocentric value orientation than Norwegians. Significantly more Norwegians $(45 \%)$ than Swedes (19 \%) responded that there were too many carnivores in their country. Historic differences in how government is perceived between Norway and Sweden may result in different attitudes towards illegal hunting and towards carnivores. Specifically, Norwegians may hold a more anthropocentric view, based on a suspicion of central authorities, whereas Swedes may hold a more ecocentric view.

Keymords: attitudes, geo-spatial distribution, human-wildlife conflicts, large carnivores, new environmental paradigm, Scandinavia

\section{INTRODUCTION}

Species and ecosystems under constant pressure from a rapidly growing human population (Lindsey et al. 2004) have led to increased need for effective planning in nature conservation in order to preserve vulnerable species and their habitats, as well as society's willingness to preserve

*Correspondence: Kristin E. Gangås Tel: +47907296 14 Fax: +47 62430851 e-mail: kristin.gangas@hihm.no these species and habitats (Hampicke 1994; Lindsey et al. 2005; Romanach et al. 2007). To find acceptable solutions for species management in areas with human-wildlife conflicts, multidisciplinary socioecological approaches are required (Shivik 2006; McShane et al. 2011; Linnell \& Boitani 2012). In this paper, we examine whether the presence of carnivores (wolves Canis lupus, bears Ursus arctos, lynx Lynx lynx and wolverine Gulo gulo) is correlated with people's environmental value orientation (ranging from ecocentric to anthropocentric) and how environmental value orientation in turn relates to the acceptance of carnivores.

Environmental value orientation is the relatively stable expression of how people evaluate the environment, and is rooted in individual basic values, having both emotional and cognitive (knowledge) components (Fransson \& Garling 1999; Schultz \& Zelezny 1999; Milfont \& Duckitt 2010; Heberlein 2012b). Here, we used the new environmental paradigm (NEP), which is a conceptualized measure of people's environmental attitudes, beliefs and values, to measure people's environmental value orientation (Dunlap et al. 2000; Ardahan 2012). Previous studies (Kaltenborn \& Bjerke 2002; Rauwald \& Moore 2002; Hunter \& Rinner 2004; Berenguer et al. 2005; Kaltenborn et al. 2008; Luo \& Deng 2008; Ardahan 2012) and conceptual and psychometric testing (Stern et al. 1995; Pierce et al. 1997) have shown that high NEP scores are correlated with pro-environmental values (Dunlap et al. 2000). Low NEP scores are associated with anthropocentrism, where humans view nature solely as a source of food and water. A person with a high anthropocentric score is likely to be sceptical to the likelihood of a future ecological crisis or severe climate changes (Gerhard 2004). In contrast, high NEP scores are associated with ecocentrism, where nature is seen to have intrinsic value regardless of human utilitarian needs, and that humans are an integral part of the environment (Kortenkamp \& Moore 2001; Hunter \& Rinner 2004). However, we should view the concept of anthropocentrism to ecocentrism not as a dichotomy, but as a gradient.

Recovery of large carnivore populations is a major challenge in many parts of the world (Noss et al. 1996; Linnell et al. 2010). Situations where the human-wildlife conflict depends on large carnivores are well suited to investigating society's environmental value orientation because carnivore presence varies spatially (for example between communities or countries) and attitudes towards large carnivores are generally extreme. As conflicts mount due to the recovery of carnivores, 
wildlife managers have to consider a range of stakeholders' interests including carnivore conservation, predation on livestock, predation of game species, killing of hunting dogs, and the fear of human injuries and fatalities (Naughton-Treves et al. 2003; Manning et al. 2009; Treves et al. 2009; BarnoweMeyer et al. 2010; Marucco \& McIntire 2010).

In Scandinavia, the public has periodically opposed the protection of large carnivores (Bjerke \& Kaltenborn 1999; Bjerke et al. 2000; Sjölander-Lindqvist 2007) followed by extensive illegal hunting of all large carnivore species (Andren et al. 2006; Persson et al. 2009; Liberg 2012). In particular, farmers and hunters felt they were excluded from participation and involvement in carnivore management by central authorities (Ericsson \& Heberlein 2003; Skogen 2003). In other parts of the world, Lindsey et al. (2006) showed how local participation by trophy hunters in Africa contributed to wildlife conservation, while hunters in Wisconsin did not support wolf conservation in their area (Treves \& Martin 2011; Bruskotter \& Fulton 2012). In Scandinavia, hunters generally do not support the conservation of large carnivores (Ericsson \& Heberlein 2003; Roskaft et al. 2007). These hunters see themselves as important wildlife stewards, and express the opinion that local knowledge is more important than scientific knowledge for setting hunting quotas for large carnivores. Thus, Scandinavian hunters may not support protection of carnivores, but they are still concerned with animal welfare and the role of carnivores in the ecosystem (Kaltenborn et al. 2013).

The recovery of carnivore populations worldwide has been accompanied by an increase in studies that investigate the human and institutional responses to these recoveries (Bisi et al. 2007; Roskaft et al. 2007; Heberlein et al. 2008; Gangaas et al. 2013). However, few studies have examined relationships between basic life values such as general environmental value orientation and attitudes towards large carnivores (Bjerke et al. 1998a). Our study addresses these gaps. Specifically, we hypothesize that: (1) the presence of carnivores predicts people's environmental value orientation, and (2) people's value orientation in turn predicts attitudes towards carnivores. More specifically, we expect that people with more ecocentric value orientation will have higher acceptance for carnivores than people with an anthropocentric value orientation. However, due to the 'not in my back yard' (NIMBY) effect (Ericsson et al. 2008; Lidskog \& Elander 1992), we predict that even ecocentric respondents, who might be positive to protection of large carnivores, do not accept carnivores in their home municipality.

\section{METHODS}

\section{Study area}

\section{Agriculture traditions}

The sample of respondents who replied to our questionnaire covered all the Scandinavian Peninsula consisting of Norway and Sweden (see below). These two neighbouring countries, with a long common history, have several characteristic differences with regard to traditions, agriculture and environmental policies. In terms of domestic animals vulnerable to predation by large carnivores, the semi-domestic free-ranging reindeer (Rangifer spp.) dominates the northern part of Scandinavia, while free-ranging domestic sheep (Ovis spp.) are found all over Norway, but not in Sweden. Moreover, sheep graze freely and unattended in uncultivated land in Norway; Norwegian agriculture is dependent on this uncultivated land. The Swedish human population currently stands at 9.6 million people $\left(26\right.$ people $\left.\mathrm{km}^{-2}\right)$, while there are 5.1 million people in Norway $\left(18\right.$ people $\mathrm{km}^{-2}$ ) (see Statistics Norway at www.ssb.no and Statistics Sweden at www.scb.se), and $84 \%$ of the human population is clustered around cities in both countries (see www.globalis.no). The resulting rural population density is 4.2 people $\mathrm{km}^{-2}$ in Sweden and 2.9 people $\mathrm{km}^{-2}$ in Norway. The proportion of total land area used for agricultural purposes is $6.4 \%$ in Sweden, and $2.7 \%$ in Norway (see www.globalis.no). Agriculture represents approximately $3.2 \%$ of total employment in Sweden and $2.5 \%$ in Norway.

As Norway is not a European Union (EU) member, the country has maintained a district policy where governmental subsidies are available to support farming, animal husbandry and human settlements throughout the country (Sorensen 2003; Otterlei \& Sande 2010). Norwegian agriculture is among the most highly subsidized in Europe (see www.oecd.org). When Sweden became member of the EU, their subsidies increased as they had no tradition of subsidized agriculture. However, Swedish subsidies are almost half of what the Norwegian government pays, and farmers in Sweden are mainly compensated for the loss of income by differences in food prices. Therefore, subsidies in Sweden are not directed towards food production or animal husbandry, as they are in Norway (see www.jordbruksverket.se).

Forestry is another important industry in both countries. The state and state-owned companies own $7 \%$ of productive forestland in Norway, and $17 \%$ in Sweden. Private forest corporations and family enterprises own $77 \%$ of the forest in Norway, and $56 \%$ of the forest in Sweden (Barklund 2009). In 2010 , the forest industry contributed $0.6 \%$ of gross domestic product (GDP) in Norway (see www.ssb.no) and 2.4\% GDP in Sweden (see www.skogstyrelsen.se).

\section{Management and politics}

Carnivore conservation in Scandinavia shifted from eradication and state bounties in early 1900 (Linnell et al. 2010) to total protection, followed by current year-toyear regulations based on hunting quotas and adaptive management (Ericsson et al. 2004; Bull et al. 2009). In Sweden, the brown bear received protection in 1913 and the lynx in 1927 (see www.artfakta.se). In Norway, regulations were adopted in the 1970 s to protect all carnivores (Swenson et al. 1995). Today, both Norwegian and Swedish management allow harvest of all carnivores, either by quotas or hunting licences. Swedish membership of the $\mathrm{EU}$ is accompanied by additional guidelines for carnivore 
Table 1 The questions used in the questionnaire to estimate the new environmental paradigm (NEP) answered in a five interval Likert-type scale; 'highly disagree', 'disagree', 'neither agree nor disagree', 'agree', and 'highly agree'. The NEP-value for each respondent was estimated as the mean of the seven answers where 'highly disagree' was given the value 1 and 'highly agree' the value 5 . Significant differences between Norway and Sweden are indicated: ${ }^{*} p=0.001$ and ${ }^{* *} p<0.001$.

\begin{tabular}{|c|c|c|c|}
\hline \multirow[t]{2}{*}{ NEP statement } & \multicolumn{2}{|c|}{ Mean NEP $( \pm S E)$} & \multirow[t]{2}{*}{$p$} \\
\hline & $\begin{array}{l}\text { Normay } \\
(n=1507)\end{array}$ & $\begin{array}{l}\text { Sweden } \\
(n=1014)\end{array}$ & \\
\hline (1) The balance in nature is delicate and easily upset & $3.94(0.03)$ & $4.21(0.03)$ & $* *$ \\
\hline (2) Humans are severely abusing the environment & $3.45(0.03)$ & $3.76(0.03)$ & $* *$ \\
\hline (3) The so-called 'ecological crisis' facing human kind has been greatly exaggerated & $3.14(0.03)$ & $2.66(0.03)$ & $* *$ \\
\hline (4) Plants and animals have the same rights to life on earth as humans & $3.96(0.03)$ & $4.23(0.03)$ & ** \\
\hline (5) The balance of nature is sufficiently stable to withstand the impacts from a modern industrial society & $2.63(0.03)$ & $2.47(0.03)$ & * \\
\hline (6) If things continue on their present course we will soon experience a major ecological catastrophe & $3.11(0.03)$ & $3.45(0.03)$ & $* *$ \\
\hline (7) Human ingenuity will ensure future life and living conditions on Earth & $3.12(0.03)$ & $3.07(0.03)$ & $* *$ \\
\hline
\end{tabular}

management, including minimum carnivore population sizes that have to be reached before carnivore populations can be controlled by hunting. The quotas or licences are set annually depending on population estimates based on monitoring programmes adapted to each carnivore species, including scat analyses, snow tracking, radio-collared individuals or DNA analyses (Hedmark \& Ellegren 2007; Linnell et al. 2007). The Norwegian management goals for carnivore population abundance are much lower than in Sweden (www.rovviltportalen.no; www.naturvardsverket.se).

\section{Carnivores}

After total absence in the late 1960s, wolves recolonized Scandinavia in 1978 (Wabakken et al. 2001) and the population today is approximately 330 individuals (Wabakken et al. 2013). The brown bear population was as low as 130 individuals in the 1920-1930s, but had increased to more than 2500 individuals in 1995 (Swenson et al. 1995) and was c. 3000-3500 individuals in 2012 (www.rovdata.no; www.naturvardsverket.se). The wolverine and lynx populations are c. 1000 and 2000 individuals, respectively (Norwegian Directorate for Nature Management, unpublished data 2010; Swedish Environmental Protection Agency, unpublished data 2010). Sweden has the major share of large carnivores, but none of these species are evenly distributed across the peninsula (Appendix 1, Fig. S1, see supplementary material at Journals.cambridge.org/ENC).

\section{Survey}

\section{Environmental attitudes}

The original new environmental paradigm (NEP) consisted of a 12-item questionnaire (Dunlap \& Vanliere 1978), but a smaller number of questions can produce sufficient inter-item reliability and validity (Bjerke \& Kaltenborn 1999; Dunlap 2008; Kaltenborn et al. 2008). Here we used a seven-item version with a five interval Likert-type scale: 'highly disagree', 'disagree', 'neither agree nor disagree', 'agree' and 'highly agree'. The seven NEP questions measure different aspects of environmental beliefs, which reflect how people think about environmental changes and how they view their role in the environment (Table 1). The NEP score for each respondent was estimated as the mean of the seven answers, where highly disagree was given the value 1 , and highly agree the value 5 (Dunlap et al. 2000).

\section{Attitudes tomards carnivores}

All respondents were asked if they found the carnivore situation in their own country to be one of the following: 'Too many carnivores', 'Suitable amount of carnivores' or 'Too few carnivores', and whether they could accept illegal hunting of wolf/lynx/bear/wolverine. In addition, the respondents had to choose one of three statements: (1) 'I cannot under any circumstances accept carnivores in my country'; (2) 'I can accept that carnivores establish freely'; or (3) 'I can accept that carnivores establish in my country under certain circumstances (e.g. zoning, removal of carnivores killing sheep)'. Those that could not accept carnivores under any circumstances (question 1) were additionally asked if they were willing to conduct illegal hunting to prevent carnivore establishment (Likert scale; Appendix 1, Fig. S2, see supplementary material as Journals.cambridge,org/ENC). Those that accepted carnivores became established freely (question 3) were additionally asked if they could live in an area inhabited by wolf/lynx/bear/wolverine (Likert scale).

\section{Sampling design}

We used a geographically stratified sampling where four or five individuals in each municipality in the two countries responded to the questionnaire (434 and 290 municipalities in Norway and Sweden, respectively). This sampling ensured that all locations (rural or urban) were presented and weighted equally in the analyses, enabling correlation of human attitudes described from the questionnaire with variation in carnivore densities.

A data collection company (www.norstat.no) conducted the survey by telephone, and based its sample on existing public registers. The interviewer followed a strict protocol 
dictated by standard research ethics, including presenting the purpose of the study, and stating that participation was entirely voluntary, how long the interview would take, and how the results would be used. There were 2521 respondents (1507 in Norway and 1014 in Sweden), a response rate of c. $15 \%$, which is common for telephone surveys. However, as the sample represents a very small proportion of people living in high density areas such as cities and suburban areas, it cannot be used as a measure of the mean opinion of people living in a specific region (for example a county) or country.

\section{Statistical procedures}

\section{Predicting NEP}

To describe the variation in the NEP scores we used a linear mixed model (Zuur et al. 2009), where county was considered a random effect and the following predictor variables as fixed effects: number of carnivores living in the respondent's county, number of free-ranging sheep, whether the respondent thought they lived in a county with strong hunting traditions (Likert scale 1-5), if the respondent had a negative experience with carnivores such as loss of sheep or dog, home country, and covariates describing the respondent (such as age, gender, education level and income). The covariates can be important predictors of attitudes, but we do not discuss them further. Education level was used as a continuous variable from secondary school, high school, university undergraduate and/or graduate degree $(\mathrm{MSc}, \mathrm{PhD})$. Carnivore densities are based on data from national wildlife databases (see www.dirnat.no and www.naturvardsverket.se). The most parsimonious model was selected using a step-wise procedure and AIC (Burnham \& Anderson 1998). First we selected the two most parsimonious models including only the carnivore predictors, and only the demographic covariates. The selected carnivore and covariate models were then combined in a full model with hunting traditions, negative experience with carnivores and country. We then used a backwards selection procedure based on AIC values. Finally, we entered each of the removed variables, one at a time, to see if they could improve the selected model. From all models, we selected that with the lowest AIC as our final most parsimonious model. All analyses were done using statistical procedures available in $\mathrm{R} 2.13 .1$ (http://cran.r-project.org/). GIS tools were used to visualize the NEP scores on maps with ArcMap 10 (ESRI).

\section{Attitudes tomards carnivores}

To analyse how the respondents' NEP scores were associated with attitudes towards carnivores, we categorized individual scores as anthropocentric when NEP $<2.8$, neutral when $2.8 \leq \mathrm{NEP}<4.0$, and ecocentric when NEP $\geq 4.0$, these threshold values being based on the distribution of the NEP scores.

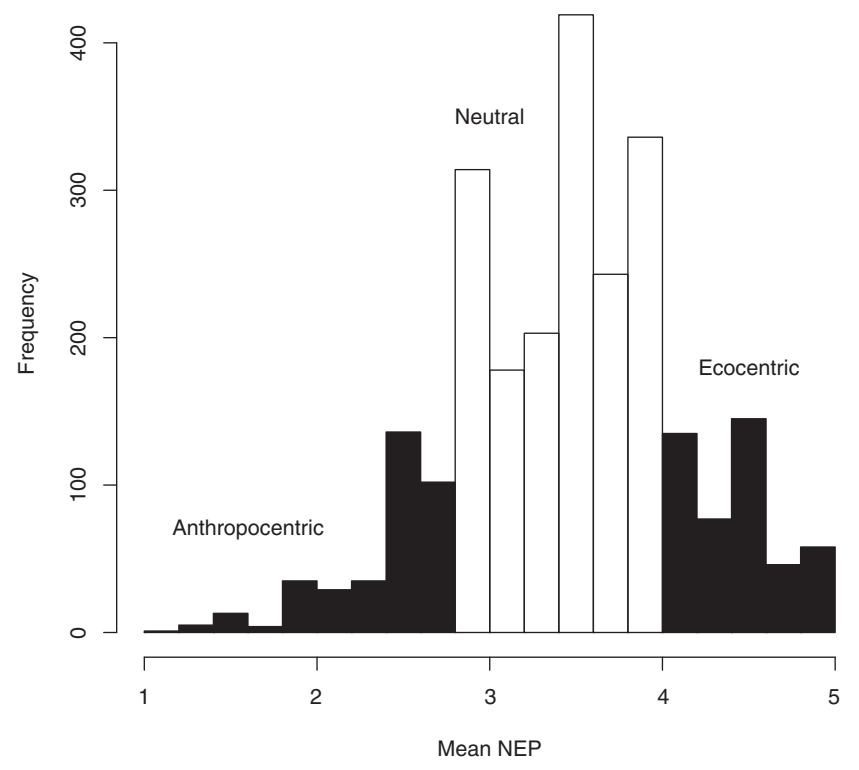

Figure 1 The distribution of the mean NEP scores from the seven NEP questions in the survey. The black bars to the right represent the respondents characterized as 'ecocentric', the black bars to the left represent the respondents characterized as 'anthropocentric', and the white bars the 'neutral' respondents.

\section{RESULTS}

\section{New environmental paradigm (NEP)}

The most parsimonious model explaining the individual mean NEP (Fig. 1) included country, age of respondent, gender and education level (AIC $=4894.14$; Tables 2 and 3), while the second best model also included whether the respondent had any negative experience with carnivores $(\triangle \mathrm{AIC}=3.45)$. Neither income $(\triangle \mathrm{AIC}>25.85)$ nor carnivore densities $(\triangle \mathrm{AIC}>26.31)$ improved the model.

Swedes reported higher ecocentric values than Norwegians in all seven NEP questions (Table 1; Fig. 2), resulting in higher mean NEP scores $( \pm \mathrm{SE})$ in Sweden $(3.65 \pm 0.02$; Table 2) than Norway $(3.38 \pm 0.02$; Table 3$)$. However, Norwegian mean NEP scores were also skewed towards an ecocentric orientation. Males were more ecocentric than females, education level was positively correlated with NEP scores (namely a higher degree of ecocentrism), while age was negatively correlated with NEP (namely a higher degree of anthropocentrism; Table 3).

\section{NEP and attitudes towards carnivores}

With regard to the main question about how respondents found the carnivore situation in their own country, Swedes were more positive towards carnivores $\left(\chi^{2}=190.52, \mathrm{df}=2\right.$, $n=2521, p<0.001)$. In particular, fewer Swedes thought there were too many carnivores in their country, and acceptance of carnivores increased with increasing (more ecocentric) NEP scores. In Sweden, 187 people found there 
Table 2 AIC values for the seven models with lowest AIC, and results for some of the other models used to explain mean NEP scores. The predictor 'neg experience' indicates the respondent has had a negative experience with carnivores, such as the loss of sheep or dogs; 'sheep' are the number of free-ranging sheep in the county of the respondent. Education level was used as a continuous predictor, as this provided models with $\triangle \mathrm{AIC} \geq 14.01$ lower than models where education level was a categorical variable with four levels.

\begin{tabular}{llr}
\hline \hline Model & AIC & $\Delta A I C$ \\
\hline The most parsimonious models & & \\
Country + education level + gender + age & 4894.19 & 0 \\
Country + education level + gender + age + neg experience & 4897.64 & 3.45 \\
Country + education level + gender & 4900.57 & 6.38 \\
Country + education level + gender + neg experience & 4903.96 & 9.77 \\
Country + education level + gender + age + sheep + neg experience & 4907.60 & 13.41 \\
Country + education level + age + gender + income & 4920.04 & 25.85 \\
Country + education level + gender + age + lynx + sheep + neg experience & 4920.50 & 26.31 \\
Other models & & \\
Full model & 5000.76 & 106.57 \\
Country & 5013.56 & 119.37 \\
Sheep free ranging + hunting traditions + neg experience & 5043.81 & 149.62 \\
Null model (intercept) & 5046.43 & 152.24 \\
Wolverine + wolf + bear + lynx & 5087.22 & 193.03 \\
\hline \hline
\end{tabular}

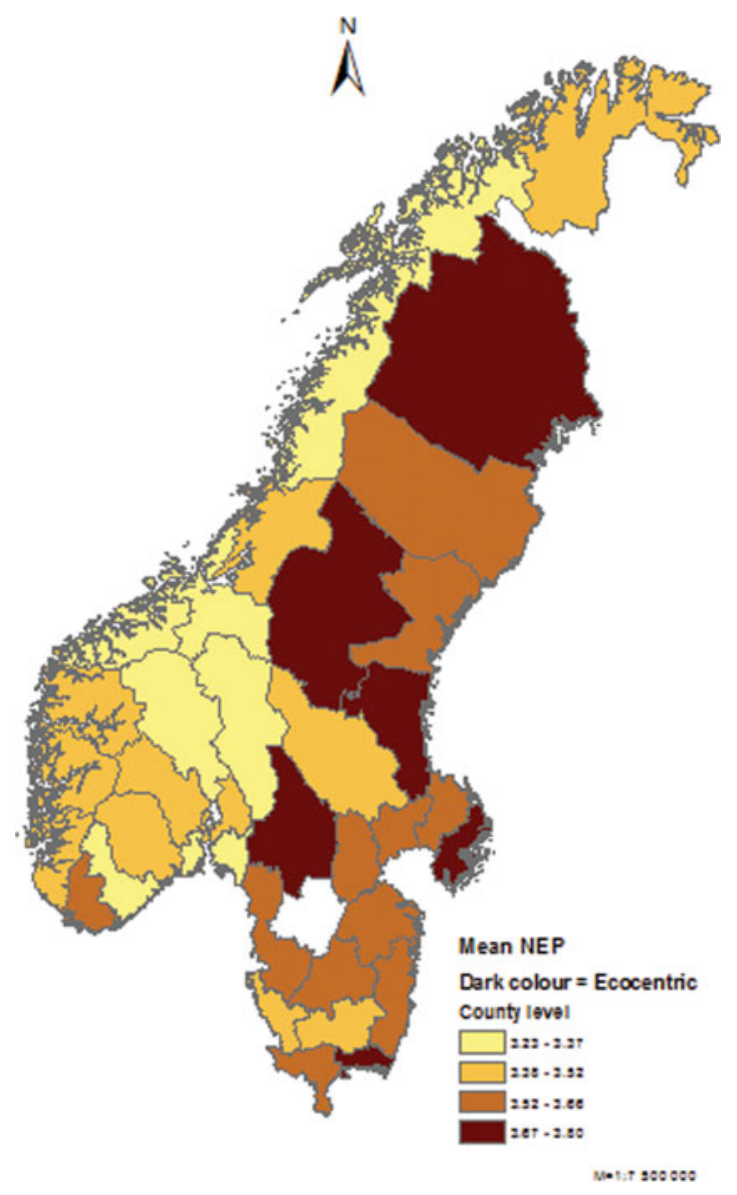

Figure 2 Map showing mean NEP scores for each county in Norway and Sweden. The darker the colour of the county the more ecocentric the mean value.
Table 3 Parameter estimates from the most parsimonious model predicting the mean NEP value of individuals.

\begin{tabular}{llcl}
\hline \hline Predictor & Level & Estimate & SE \\
\hline Intercept & & 3.268 & 0.057 \\
Country & Norway & 0 & - \\
& Sweden & 0.270 & 0.029 \\
Gender & Female & 0 & - \\
& Male & 0.219 & 0.026 \\
Age & & -0.003 & 0.001 \\
Education level & & 0.079 & 0.012 \\
\hline \hline
\end{tabular}

were 'too many' carnivores (mean NEP score \pm SE was 3.40 $\pm 0.03), 664$ reported that carnivore numbers were 'suitable' $(3.64 \pm 0.02)$ and 163 felt there were 'too few' carnivores $(3.93 \pm 0.04)$. The corresponding numbers from Norway were 'too many': 679 (3.20 \pm 0.02$)$, 'suitable': 659 (3.45 $\pm 0.02)$ and 'too few': $169(3.75 \pm 0.04)$. The mean NEP scores differed significantly between Norway and Sweden $(p<0.005)$. This national difference was still present when comparing the frequency of respondents to various scenarios of living with carnivores: $7 \%$ of the Norwegians and 2 $\%$ of the Swedes could not accept carnivores under any circumstances. However, the majority of both Norwegians and Swedes answered that they could accept carnivores under certain conditions (Norway $80 \%$; Sweden $71 \%$ ) and that they could accept carnivores being established freely (Norway $13 \%$; Sweden $27 \%$; Table 4).

Among the respondents that could not under any circumstances accept carnivores in their own country $(100$ Norwegians and 21 Swedes), $4 \%$ and $14 \%$ of Norwegians and Swedes, respectively, reported an ecocentric attitude, while $41 \%$ and $29 \%$ of Norwegians and Swedes, respectively, 
Table 4 The number of respondents $(n)$ in Norway and Sweden answering that they: (1) do not accept carnivores under any circumstances, (2) accept carnivores are freely established, or (3) accept that carnivores become establish under certain conditions. For each of these questions, we show the percentage of the respondents belonging to the anthropocentric-ecocentric gradient. For those respondents that could not accept carnivores under any circumstances, we also asked if they were willing to conduct illegal hunting themselves to prevent establishment (1.1), and, for those who accepted carnivores became freely established, we also asked if they were personally willing to live in carnivore areas (2.1).

\begin{tabular}{|c|c|c|c|c|c|}
\hline \multirow[t]{2}{*}{ Question } & \multirow[t]{2}{*}{ Country } & \multirow[t]{2}{*}{$n$} & \multicolumn{3}{|c|}{ NEP scores (\%) } \\
\hline & & & $\begin{array}{c}<2.8 \\
\text { Anthropocentric }\end{array}$ & $\begin{array}{c}2.8- \\
3.9 \\
\end{array}$ & $\begin{array}{c}\geq 4.0 \\
\text { Ecocentric }\end{array}$ \\
\hline \multirow[t]{2}{*}{1 I do not accept carnivores under any circumstances } & Norway & 100 & 41 & 55 & 4 \\
\hline & Sweden & 21 & 29 & 57 & 14 \\
\hline \multirow[t]{2}{*}{ 1.1 I am willing to conduct illegal hunting to prevent carnivore establishment } & Norway & 36 & 52 & 42 & 6 \\
\hline & Sweden & 2 & 0 & 100 & 0 \\
\hline \multirow[t]{2}{*}{2 I accept that carnivores establish freely } & Norway & 200 & 12 & 58 & 26 \\
\hline & Sweden & 270 & 7 & 68 & 24 \\
\hline \multirow[t]{2}{*}{ 2.1 I am not willing to live in carnivore areas myself } & Norway & 49 & 20 & 60 & 20 \\
\hline & Sweden & 66 & 5 & 65 & 30 \\
\hline \multirow[t]{2}{*}{3 I accept that carnivores establish under certain conditions } & Norway & 1207 & 17 & 69 & 14 \\
\hline & Sweden & 723 & 9 & 60 & 31 \\
\hline
\end{tabular}

reported an anthropocentric view. However, these differences were not significant $\left(\chi^{2}=3.88, \mathrm{df}=2, n=121, p=0.144\right.$; Table 4). Out of the 100 Norwegians, $36 \%$ were willing to shoot carnivores illegally, while, in Sweden, only $10 \%$ who could not accept carnivores were willing to illegally hunt carnivores (Table 4).

Among those respondents accepting that carnivores become established freely, there was no difference in NEP scores between countries $\left(\chi^{2}=4.26\right.$, df $=2, n=470, p=$ 0.119 ; Table 4 ). In both countries, about $25 \%$ of respondents were unwilling to live with carnivores (Table 4), although respondents were more ecocentric in Sweden than Norway $\left(\chi^{2}=7.48, \mathrm{df}=2, n=115, p=0.024\right.$; Table 4$)$.

Most respondents (1207 in Norway and 723 in Sweden) could accept carnivores under certain conditions, such as in protected areas or if carnivores that kill livestock were removed. More Swedes that accepted carnivores under certain conditions had ecocentric NEP scores than Norwegians $\left(\chi^{2}=89.72, \mathrm{df}=2, n=1930, p<0.001 ;\right.$ Table 4$)$.

\section{DISCUSSION}

NEP scores were negatively correlated with acceptance of illegal hunting and the wish for fewer predators, corroborating previous studies (Bjerke \& Kaltenborn 1999). NEP scores were mainly affected by national differences and demographic covariates, and not associated with the presence of carnivores. Ecocentric value orientation was more common among Swedes than Norwegians. Even Swedes that answered in a rather anthropocentric way, such as acceptance of illegal hunting or unwillingness to live in carnivore areas, showed a somewhat more ecocentric orientation than Norwegians. A person may well have a positive view of nature and carnivores in general, and at the same time support behaviour that is not associated with an ecocentric value orientation. The question is how central the attitude(s) is to that person's fundamental belief system. People change their behaviour when personally affected, or they may actually have a different personal norm than the attitude they report (Heberlein 2012a). This gap between people's attitudes and how they might act also depends on the extremity of the behaviour, and the correlation between behaviour and general environmental value orientation is often indirect and weak (Manfredo 2008; Heberlein 2012a).

As expected, respondents who did not favour carnivores in their country reported more anthropocentric attitudes than those who could accept carnivores becoming freely established in their country. However, $25 \%$ of those respondents claiming that carnivores should be able to become established were unwilling to live in a carnivore area themselves. This is likely an example of the common discrepancy between general attitudes toward a subject or issue and specific behavioural intentions. Environmental value orientation represents an environmental world view; it is possible that individuals with an ecocentric orientation believe that unrestricted carnivore establishment is more equitable than having certain carnivore zoning areas resulting in more burden for inhabitants of these areas.

Even though our geographical stratified sampling does not describe the mean Norwegian or Swede, the differences in environmental value orientation (NEP scores) and carnivore attitudes between Norway and Sweden are noteworthy. Both countries have democratically-elected governments with comparable economy and education levels (Otterlei \& Sande 2010). They also share the same carnivore populations and the same obligations to large carnivore protection, though their carnivore population abundances differ significantly (Woodroffe et al. 2005; Otterlei \& Sande 2010). Moreover, contemporary Scandinavia is thought to be homogenous across a range of social and economic factors, including law 
enforcement, political stability, political trust, government effectiveness, rule of law, redistribution of goods and benefits, as well as control of corruption and accountability (Svallfors 1999; Sinani 2010). In terms of management practices and environmental protection, Norway and Sweden tend to be characterized as ecologically and politically similar (Gulbrandsen 2005; Gulbrandsen 2008). On social issues, however, some studies have shown that Swedes tend to be more egalitarian. For instance, Sweden is more positive towards gender equality, while Norwegians tend to be more xenophobic (Knudsen 1997; Jakobsson \& Kotsadam 2010). These differences may indicate important social and national identity distinctions; cultural traits, including fear of the unknown, can be important in understanding how societies deal with growing carnivore populations, and are also highly relevant for similar considerations outside Scandinavia.

In Norway, there is also a strong tradition of communityled governance, where local communities have considerable influence on national laws and decision-making (Otterlei \& Sande 2010). The protection of carnivores by law in the 1970s was perceived by some other rural inhabitants as being a national government imposed decision, where 'external forces' permitted the recolonization of Norway by large carnivores (Skogen \& Krange 2003; Kleiven et al. 2004). This opposition to central authorities may be absent or less important in Sweden, where it is more customary to determine policy at a national level (Otterlei \& Sande 2010). The Swedish tradition of central government may also enable more stringent conservation of nature than in Norway (Otterlei \& Sande 2010), exemplified by the much earlier Swedish protection of brown bears and lynx, as compared to Norway (Swenson et al. 1995; see www.artfakta.se). Hence, centralized carnivore management may be considered as a more provocative policy among Norwegians than Swedes, motivating rebellion against central authorities (Muth \& Bowe 1998), and leading to Norwegians being more accepting of and willing to commit illegal hunting (Otterlei \& Sande 2010; Krange et al. 2012). For example, rural men with strong hunting traditions resist carnivore re-establishment, especially the wolf, as an act of cultural or social protest (Skogen 2001, 2003; Skogen \& Thrane 2008).

Kaltenborn et al. (1998) used the NEP scale to look at how attitudes toward predators were reflected by environmental value orientation. They grouped their respondents into subgroups as farmers, wildlife managers and research biologists, and found significant differences between farmers' NEP scores and those of the other two groups (Bjerke \& Kaltenborn 1999). Sheep farmers and hunters have traditionally been associated with anthropocentric environmental values (Kaltenborn et al. 1998); Vitterso et al. 1998; Bjerke \& Kaltenborn 1999). We were unable to confirm this in our study, as rural traditions (such as sheep farming or big game hunting) were not related to the NEP scores. Even the experience of losing sheep or hunting dogs to large carnivores was not reflected in our respondents' environmental value orientation. However, other studies have shown a higher variation in hunters' environmental value orientation compared to that of sheep farmers (Bjerke $e t$ al. 1998b, 2000; Vitterso et al. 1998; Ericsson \& Heberlein 2003; Heberlein \& Ericsson 2008).

The lack of relationship between NEP scores and experiences, such as loss of dogs or livestock, has similarities to studies from South Africa, where livestock owners from two apparently similar communities experienced loss of cattle to predators, but showed highly divergent attitudes towards predators (Lagendijk \& Gusset 2008). The community with a tradition of hostile attitudes toward lions (Panthera leo) showed lower acceptance of predation and presence of predators compared to the community that did not have this tradition of hunting and killing lions, even though the consequences of having predators in their neighbourhood were the same (Gusset et al. 2008; Lagendijk \& Gusset 2008). Therefore, cultural differences played an important part in explaining these highly divergent attitudes towards lions (Lagendijk \& Gusset 2008).

Albeit attitudes toward carnivores in general have become more positive in the last century, studies from Finland and Sweden show how attitudes toward wolves turn in a negative direction when carnivores became established close to people (Bisi et al. 2007; Heberlein \& Ericsson 2008). The most positive attitudes toward the wolf may be found among people who have the least experience with them (Williams et al. 2002). In contrast, more negative attitudes toward the wolf exist among urban people who had little contact with the countryside or had no experience with wolves (Heberlein \& Ericsson 2008). These examples illustrate the complexity and multi-scale nature of the human-carnivore conflict.

\section{CONCLUSION}

Environmental value orientation is generally thought to influence attitudes towards carnivores, and to some extent the behavioural intentions related to carnivores, for instance willingness to participate in hunting, commit illegal hunting or support for conservation (Fransson \& Garling 1999; Kaiser et al. 1999; Hunter \& Rinner 2004; Milfont \& Duckitt 2010). Differences in environmental value orientation between Norway and Sweden show that cultural differences may overshadow the presence of, or experience with carnivores, together with a generally greater acceptance of central authorities in Sweden compared to Norway. This difference in attitudes and responses to governance and management actions between Norway and Sweden explains the difficulties in the management of the common carnivore population across the Scandinavian Peninsula. Combined with spatial ecological descriptors of carnivore sustainability and economical descriptors, our spatial approach may form the basis for identifying optimal areas for carnivore establishment. Policy and management practices and concrete humanwildlife conflicts occur at different scales (Ericsson \& Heberlein 2003; Ericsson et al. 2008), and multi-scale studies are needed to unravel the relationships between local, regional, 
national and international responses to carnivore conservation and expanding carnivore populations.

\section{ACKNOWLEDGEMENTS}

This study is funded by Hedmark University College. We are grateful to Peter Kiffney for the valuable comments on an earlier draft of the paper and for proofreading the English.

\section{References}

Andren, H., Linnell, J.D.C., Liberg, O., Andersen, R., Danell, A., Karlsson, J., Odden, J., Moa, P.F., Ahlqvist, P., Kvam, T., Franzen, R. \& Segerstrom, P. (2006) Survival rates and causes of mortality in Eurasian lynx (Lynx lynx) in multi-use landscapes. Biological Conservation 131: 23-32.

Ardahan, F. (2012) The new ecological paradigm (NEP scale) score of Turkish mountaineers/rock climbers, cyclists and trekkers. Energy Education Science and Technology Part B. Social and Educational Studies 4: 2035-2046.

Barklund, A. (2009) The Swedish Forestry Model. Stockholm, Sweden: Royal Swedish Academy of Agriculture and Forestry.

Barnowe-Meyer, K.K., White, P.J., Davis, T.L., Smith, D.W., Crabtree, R.L. \& Byers, J.A. (2010) Influences of wolves and high-elevation dispersion on reproductive success of pronghorn (Antilocapra americana). Fournal of Mammalogy 91: 712-721.

Berenguer, J., Corraliza, J.A. \& Martin, R. (2005) Rural-urban differences in environmental concern, attitudes, and actions. European Fournal of Psychological Assessment 21: 128-138.

Bisi, J., Kurki, S., Svensberg, M. \& Liukkonen, T. (2007) Human dimensions of wolf (Canis lupus) conflicts in Finland. European Fournal of Wildlife Research 53(4): 304-314.

Bjerke, T. \& Kaltenborn, B.P. (1999) The relationship of ecocentric and anthropocentric motives to attitudes toward large carnivores. Fournal of Environmental Psychology 19: 415-421.

Bjerke, T., Odegardstuen, T.S. \& Kaltenborn, B.P. (1998a) Attitudes toward animals among Norwegian adolescents. Anthrozoos 11: 79 86.

Bjerke, T., Reitan, O. \& Kellert, S.R. (1998b) Attitudes toward wolves in southeastern Norway. Society and Natural Resources 11: 169-178.

Bjerke, T., Vitterso, J. \& Kaltenborn, B.P. (2000) Locus of control and attitudes toward large carnivores. Psychological Reports 86: 37-46.

Bruskotter, J.T. \& Fulton, D.C. (2012) Will hunters steward wolves? A comment on Treves and Martin. Society and Natural Resources 25: 97-102.

Bull, J., Nilsen, E.B., Mysterud, A. \& Milner-Gulland, E.J. (2009) Survival on the border: a population model to evaluate management options for Norway's wolves Canis lupus. Wildlife Biology 15: 412-424.

Burnham, S.T \& Anderson, D.R. (1998) Model Selection and Multimodel Inference: a Practical Information-Theoretic Approach. New York, NY, USA: Springer.

Dunlap, R.E. (2008) The new environmental paradigm scale: from marginality to worldwide use. Fournal of Environmental Education 40: 3-18.

Dunlap, R.E. \& Vanliere, K.D. (1978) New environmental paradigm. Fournal of Environmental Education 9: 10-19.
Dunlap, R.E., Vanliere, K.D., Mertig, A.G. \& Jones, R.E. (2000) Measuring endorsement of the new ecological paradigm: a revised NEP scale. Fournal of Social Issues 56: 425-442.

Ericsson, G., Bostedt, G. \& Kindberg, J. (2008) Wolves as a symbol of people's willingness to pay for large carnivore conservation. Society and Natural Resources 21: 294-309.

Ericsson, G. \& Heberlein, T.A. (2003) Attitudes of hunters, locals, and the general public in Sweden now that the wolves are back. Biological Conservation 111: 149-159.

Ericsson, G., Heberlein, T.A., Karlsson, J., Bjarvall, A. \& Lundvall, A. (2004) Support for hunting as a means of wolf Canis lupus population control in Sweden. Wildlife Biology 10: 269-276.

Fransson, N. \& Garling, T. (1999) Environmental concern: conceptual definitions, measurement methods, and research findings. Fournal of Environmental Psychology 19: 369-382.

Gangaas, K.E., Kaltenborn, B.P. \& Andreassen, H.P. (2013) Geo-spatial aspects of acceptance of illegal hunting of large carnivores in Scandinavia. PLoS One 8: e68849. doi 10.1371/journal.pone.0068849

Gerhard, L.C. (2004) Climate change: conflict of observational science, theory, and politics. AAPG Bulletin 88: 1211-1220.

Gulbrandsen, L.H. (2005) The effectiveness of non-state governance schemes: a comparative study of forest certification in Norway and Sweden. International Environmental Agreements 5: 125-149.

Gulbrandsen, L.H. (2008) The role of science in environmental governance: competing knowledge producers in Swedish and Norwegian forestry. Global Environmental Politics 8: 99-122.

Gusset, M., Maddock, A.H., Gunther, G.J., Szykman, M., Slotow, R., Walters, M. \& Somers, M.J. (2008) Conflicting human interests over the re-introduction of endangered wild dogs in South Africa. Biodiversity and Conservation 17: 83-101.

Hampicke, U. (1994) Ethics and economics of conservation. Biological Conservation 67: 219-231.

Heberlein, T.A. (2012a) Navigating Environmental Attitudes. New York, NY, USA: Oxford University Press.

Heberlein, T.A. (2012b) Navigating environmental attitudes. Conservation Biology 26: 583-585.

Heberlein, T.A. \& Ericsson, G. (2008) Public attitudes and the future of wolves Canis lupus in Sweden. Wildlife Biology 14: 391-394.

Hedmark, E. \& Ellegren, H. (2007) DNA-based monitoring of two newly founded Scandinavian wolverine populations. Conservation Genetics 8: 843-852.

Hunter, L.M. \& Rinner, L. (2004) The association between environmental perspective and knowledge and concern with species diversity. Society and Natural Resources 17: 517-532.

Jakobsson, N. \& Kotsadam, A. (2010) Do attitudes toward gender equality really differ between Norway and Sweden? Fournal of European Social Policy 20: 142-159.

Kaiser, F.G., Wolfing, S. \& Fuhrer, U. (1999) Environmental attitude and ecological behaviour. Fournal of Environmental Psychology 19: 1-19.

Kaltenborn, B.P., Bjerke, T. \& Strumse, E. (1998) Diverging attitudes towards predators: do environmental beliefs play a part? Human Ecology Reviem 5: 1-9.

Kaltenborn, B.P. \& Bjerke, T. (2002) Associations between environmental value orientations and landscape preferences. Landscape and Urban Planning 59: 1-11.

Kaltenborn, B.P., Andersen, O. \& Linnell, J.D.C. (2013) Is hunting large carnivores different from hunting ungulates? Some judgments made by Norwegian hunters. Fournal for Nature Conservation 21: 326-333. 
Kaltenborn, B.P., Andersen, O., Nellemann, C., Bjerke, T. \& Thrane, C. (2008) Resident attitudes towards mountain second-home tourism development in Norway: the effects of environmental attitudes. Fournal of Sustainable Tourism 16: 664680.

Kleiven, J., Bjerke, T. \& Kaltenborn, B.P. (2004) Factors influencing the social acceptability of large carnivore behaviours. Biodiversity and Conservation 13: 1647-1658.

Knudsen, K. (1997) Scandinavian neighbours with different character? Attitudes toward immigrants and national identity in Norway and Sweden. Acta Sociologica 40: 223-243.

Kortenkamp, K.V. \& Moore, C.F. (2001) Ecocentrism and anthropocentrism: moral reasoning about ecological commons dilemmas. Fournal of Environmental Psychology 21: 261-272.

Krange, O., Tangeland, T., Sandström, C. \& Ericsson, G. (2012) Holdinger til store rovdyr $i$ Norge og Sverige : En komparativ studie av holdinger til rovdyr og rovviltforvaltning. Trondheim, Norway: Norsk institutt for naturforskning.

Lagendijk, D.D.G. \& Gusset, M. (2008) Human-carnivore coexistence on communal land bordering the Greater Kruger area, South Africa. Environmental Management 42: 971-976.

Liberg, O., Guillaume, C., Wabakken, P., Pedersen, H.C., Hobbs, N.T. \& Sand, H. (2012) Shoot, shovel and shut up; cryptic poaching slows restoration of a large carnivore in Europe. Proceedings of the Royal Society B 279: 910-915.

Lidskog, R. \& Elander, I. (1992) Reinterpreting locational conflicts: nimby and nuclear waste management in sweden. Policy and Politics 20: 249-264.

Lindsey, P.A., Alexander, R.R., du Toit,J.T. \& Mills, M.G.L. (2004) The potential contribution of ecotourism to African wild dog Lyacon pictus conservation in South Africa. Biological Conservation 123: 339-348.

Lindsey, P.A., Alexander, R.R., du Toit,J.T. \& Mills, M.G.L. (2005) The potential contribution of ecotourism to African wild dog Lycaon pictus conservation in South Africa. Biological Conservation 123: 339-348.

Lindsey, P.A., Alexander, R., Frank, L.G., Mathieson, A. \& Romanach, S.S. (2006) Potential of trophy hunting to create incentives for wildlife conservation in Africa where alternative wildlife-based land uses may not be viable. Animal Conservation 9: 283-291.

Linnell, J.D.C. \& Boitani, L. (2012) Building biological realism into wolf management policy: the development of the population approach in Europe. Hystrix. Italian Fournal of Mammalogy 23: $80-91$.

Linnell, J.D.C., Broseth, H., Odden, J. \& Nilsen, E.B. (2010) Sustainably harvesting a large carnivore? Development of Eurasian lynx populations in Norway during 160 years of shifting policy. Environmental Management 45: 1142-1154.

Linnell, J.D.C., Odden, J., Andren, H., Liberg, O., Andersen, R., Moa, P., Kvam, T., Broseth, H., Segerstrom, P., Ahlqvist, P., Schmidt, K., Jedrzejewski, W. \& Okarma, H. (2007) Distance rules for minimum counts of Eurasian lynx Lynx lynx family groups under different ecological conditions. Wildlife Biology 13: 447455.

Luo, Y.J. \& Deng, J.Y. (2008) The new environmental paradigm and nature-based tourism motivation. Fournal of Travel Research 46: 392-402.

Manfredo, M.J. (2008) Who Cares About Wildlife?: Social Science Concepts for Exploring Human-Wildlife Relationships and Conservation Issues. New York, NY, USA: Springer.
Manning, A.D., Gordon, I.J. \& Ripple, W.J. (2009) Restoring landscapes of fear with wolves in the Scottish Highlands. Biological Conservation 142: 2314-2321.

Marucco, F. \& McIntire, E.J.B. (2010) Predicting spatio-temporal recolonization of large carnivore populations and livestock depredation risk: wolves in the Italian Alps. Fournal of Applied Ecology 47: 789-798.

McShane, T.O., Hirsch, P.D., Trung, T.C., Songorwa, A.N., Kinzig, A., Monteferri, B., Mutekanga, D., Thang, H.V., Dammert, J.L., Pulgar-Vidal, M., Welch-Devine, M., Brosius, J.P., Coppolillo, P. \& O’Connor, S. (2011) Hard choices: making trade-offs between biodiversity conservation and human wellbeing. Biological Conservation 144: 966-972.

Milfont, T.L. \& Duckitt, J. (2010) The environmental attitudes inventory: a valid and reliable measure to assess the structure of environmental attitudes. Fournal of Environmental Psychology 30: 80-94.

Muth, R.M. \& Bowe, J.F. (1998) Illegal harvest of renewable natural resources in North America: toward a typology of the motivations for poaching. Society and Natural Resources 11: 9-24.

Naughton-Treves, L., Grossberg, R. \& Treves, A. (2003) Paying for tolerance: rural citizens' attitudes toward wolf depredation and compensation. Conservation Biology 17: 1500-1511.

Noss, R.F., Quigley, H.B., Hornocker, M.G., Merrill, T. \& Paquet, P.C. (1996) Conservation biology and carnivore conservation in the Rocky Mountains. Conservation Biology 10: 949-963.

Otterlei, J.B. \& Sande, A. (2010) Environmental policy and governing nature government or governance. Tidsskrift for Samfunnsforskning 51: 419-443.

Persson, J., Ericsson, G. \& Segerstrom, P. (2009) Human caused mortality in the endangered Scandinavian wolverine population. Biological Conservation 142: 325-331.

Pierce, G.R., Sarason, I.G., Sarason, B.R., Solky-Butzel, J.A. \& Nagle, L.C. (1997) Assessing the quality of personal relationships journal of social and personal relationships. 14(3): 339-356.

Rauwald, K.S. \& Moore, C.F. (2002) Environmental attitudes as predictors of policy support across three countries. Environment and Behavior 34: 709-739.

Romanach, S.S., Lindsey, P.A. \& Woodroffe, R. (2007) Determinants of attitudes towards predators in central Kenya and suggestions for increasing tolerance in livestock dominated landscapes. Oryx 41: 185-195.

Roskaft, E., Handel, B., Bjerke, T. \& Kaltenborn, B.P. (2007) Human attitudes towards large carnivores in Norway. Wildlife Biology 13: 172-185.

Schultz, P.W. \& Zelezny, L. (1999) Values as predictors of environmental attitudes: evidence for consistency across 14 countries. Fournal of Environmental Psychology 19: 255-265.

Shivik, J.A. (2006) Tools for the edge: what's new for conserving carnivores. Bioscience 56: 253-259.

Sinani, E., Stafsudd, A., Thomsen, S., Edling, C. \& Randøy, T. (2010) Corporate governance in Scandinavia: comparing networks and formal institutions. European Management Reviem 5: 27-40.

Stern, P.C., Dietz, T. \& Guagnano, G.A. (1995) The new ecological paradigm in social-psychological context. Environment and Behavior 27: 723-743.

Svallfors, S. (1999) Political trust and attitudes towards redistribution. European Societies 1: 241-268.

Sjölander-Lindqvist, A. (2007) Local identity, science and politics indivisible: the Swedish wolf controversy deconstructed. Fournal of Environmental Policy and Planning 10: 71-94. 
Skogen, K. (2001) Who's afraid of the big, bad wolf? Young people's responses to the conflicts over large carnivores in eastern Norway. Rural Sociology 66: 203-226.

Skogen, K. (2003) Adapting adaptive management to a cultural understanding of land use conflicts. Society and Natural Resources 16: $435-450$.

Skogen, K. \& Krange, O. (2003) A wolf at the gate: the anti-carnivore alliance and the symbolic construction of community. Sociologia Ruralis 43: 309.

Skogen, K. \& Thrane, C. (2008) Wolves in context: using survey data to situate attitudes within a wider cultural framework. Society and Natural Resources 21: 17-33.

Skogen, K., Mauz, I. \& Krange, O. (2008) Cry wolf! Narratives of wolf recovery in France and Norway. Rural Sociology 73: 105-133.

Sorensen, R.J. (2003) The political economy of intergovernmental grants: the Norwegian case. European Fournal of Political Research 42: 163-195.

Swenson, J.E., Wabakken, P., Sandegren, F., Bjarvall, A., Franzen, R. \& Soderberg, A. (1995) The near extinction and recovery of brown bears in Scandinavia in relation to the bear management policies of Norway and Sweden. Wildlife Biology 1: 11-25.

Treves, A., Jurewicz, R.L., Naughton-Treves, L. \& Wilcove, D.S. (2009) The price of tolerance: wolf damage payments after recovery. Biodiversity and Conservation 18: 4003-4021.
Treves, A. \& Martin, K.A. (2011) Hunters as stewards of wolves in Wisconsin and the Northern Rocky Mountains, USA. Society and Natural Resources 24: 984-994.

Vitterso, J., Kaltenborn, B.P. \& Bjerke, T. (1998) Attachment to livestock and attitudes: toward large carnivores among sheep farmers in Norway. Anthrozoos 11: 210-217.

Wabakken, P., Sand, H., Liberg, O. \& Bjarvall, A. (2001) The recovery, distribution, and population dynamics of wolves on the Scandinavian peninsula, 1978-1998. Canadian Fournal of Zoology. Revue Canadienne De Zoologie 79: 710-725.

Wabakken, P.S.L., Kojola, I., Maartmann, E., Strømseth, T.H., Flagstad., Ø., Akesson, M. \& Zetterberg, A. (2013) Ulv $i$ Skandinavia og Finland: sluttrapport for bestandsovervåking av ulv vinteren 2012-2013. Elverum, Norway: Høgskolen i Hedmark (Oppdragsrapport 5-2013).

Williams, C.K., Ericsson, G. \& Heberlein, T.A. (2002) A quantitative summary of attitudes toward wolves and their reintroduction (1972-2000). Wildlife Society Bulletin 30: 575-584.

Woodroffe, R., Thirgood, S. \& Rabinowitz, A. (2005) People and Wildlife: Conflict or Coexistence? Cambridge, UK: Cambridge University Press.

Zuur, A., Ieno, E.N., Walker, N., Saveliev, A.A. \& Smith, G.M. (2009) Mixed Effects Models and Extensions in Ecology with R. New York, NY, USA: Springer. 